\title{
Determinants of Savings and Community Loans in Ngawi District, 2010 - 2018 A Macro Economic Approach
}

\author{
Yusnardhi Indra Pradata, JJ. Sarungu, A. Suryantoro \\ Sebelas Maret University, Indonesia
}

\begin{abstract}
This study aims to analyze (1) the effect of income on community savings; (2) the effect of savings interest on community savings; (3) the effect of savings on community lending (4) the effect of loan interest on community lending; (5) the influence of external funds on community lending; (6) the right theory is applied in order to increase the receipt of savings and lending to the people of Ngawi Regency. This research is a type of quantitative research. The unit of analysis in this study is inter-time development data on the amount of savings and public loans, the determination of the interest rates for savings and loans on average per year, external funds, and income in Ngawi Regency during 2010-2018. Data analysis techniques using multiple linear regression in the form of log-linear. The results of the study found that: (1) Revenue did not have a real impact on the savings of the people of Ngawi Regency. (2) The determination of savings interest does not support the receipt of savings from the people of Ngawi Regency in BRI and Bank Jatim. (3) Savings can increase community loans in Ngawi Regency. (4) The policy for determining loan interest rates carried out at BRI and Bank Jatim is less able to have a real impact on the distribution of loans to the people of Ngawi Regency. (5) External funds are able to encourage the fulfillment of Ngawi Regency community loan disbursement. (7) Savings and less interest can be used to increase the savings and loans of the people of Ngawi Regency. This shows that the right theory applied to increase the receipt of savings and lending Ngawi Regency is Keynes's theory.
\end{abstract}

\section{Keywords}

savings, loans, savings interest; loans interest; external funds income; Keynes Theory, classical theory

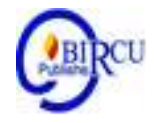

\section{Introduction}

Law Number 10 of 1998 Concerning Banking in article 4 explains that the purpose of Indonesian banking in general is to support the implementation of national development in the context of increasing equity, economic growth and national stability towards improving people's welfare. This shows that the role of banks is very important for a country's economy in terms of supporting development.

Microeconomic developments are the foundation for economic growth in Indonesia. This show is small and medium industries have good prospects to be developed and have competitiveness and competitive advantage well and contribute to employment safety. One form of microeconomics that can combine large amounts of labor with small capital is small and medium micro enterprises. (Ulfha, 2019)

The banking sector has a real contribution to the economic development of a country. Banks, especially state-owned banks, have an important role in maintaining monetary stability. A stable monetary condition will be able to make development efforts run better because the monetary capacity to finance development is getting stronger. Banks must be able to carry out their functions properly in order to ensure the implementation of development that runs on time and minimal constraints, especially from the monetary side. 
The ability of banks to collect savings and distribute loans to the public must be improved. Savings collected by banks will be able to be used to finance development, meanwhile loans or loans disbursed to the community will be able to be used as an effort to increase the ability of community capital to participate in filling development with various economic efforts undertaken by the community. This is consistent with the research of Kasiang, et al (2018) which explains that savings have an important role in financing development.

Development in accordance with government targets and targets is expected to be able to sustain economic growth. The existence of public deposits will be able to increase economic growth. This is in line with Suhel's (2015) opinion that public savings in the form of savings, time deposits and current accounts if used for various economic activities will function the same as investments which cause an increase in the region's output so that it will increase the region's income and create economic growth.

Community loans or loans also have an important role in supporting the implementation of development in order to increase economic growth. Loans that can be channeled properly show that people have economic actions that can improve their economy. This is consistent with the research findings of Beck et.al, (2012) that working capital loans have a positive influence on economic growth in various countries. The results of Sassi and Gasmi's research (2014) also found a positive effect of credit on the economic growth of 27 countries in Europe. Research by Fithriyah and Malik (2010) found that bank credit has a real and credible impact on the growth of the manufacturing industry, while the growth of the manufacturing industry will be able to increase economic growth. This economic growth is very important because it is used to describe the economic progress of a country in a certain period of time. This condition shows the importance of banking efforts in increasing lending to the public.

Banks in Ngawi Regency must be able to support monetary stability efforts to facilitate the implementation of development. Based on data from Ngawi in figures, data on receipt of savings and loan distribution to the public in 2010 - 2018 are as shown in Table 1.

Table 1. Ngawi Regency Community Savings and Loans Period 2010 - 2018 (Rupiah)

\begin{tabular}{|c|c|c|}
\hline Year & Savings & Loan \\
\hline 2010 & 626.500 .117 .000 & 1.052 .211 .684 .000 \\
\hline 2011 & 737.356 .655 .000 & 1.131 .572 .646 .000 \\
\hline 2012 & 709.714 .601 .000 & 1.380 .158 .405 .000 \\
\hline 2013 & 867.470 .380 .000 & 1.689 .549 .611 .000 \\
\hline 2014 & 1.216 .567 .655 .000 & 1.926 .511 .468 .000 \\
\hline 2015 & 1.394 .203 .595 .000 & 2.059 .332 .563 .000 \\
\hline 2016 & 1.568 .004 .000 .000 & 2.190 .021 .500 .000 \\
\hline 2017 & 1.784 .692 .000 .000 & 2.370 .058 .219 .000 \\
\hline 2018 & 2.028 .387 .989 .200 & 2.535 .719 .624 .450 \\
\hline
\end{tabular}

Source: BPS Ngawi Regency

Distribution of loans or loans to the public during the period 2010 - 2018 tends to increase from year to year. The percentage of the development of savings and loans in Ngawi Regency can be seen in the following figure: 


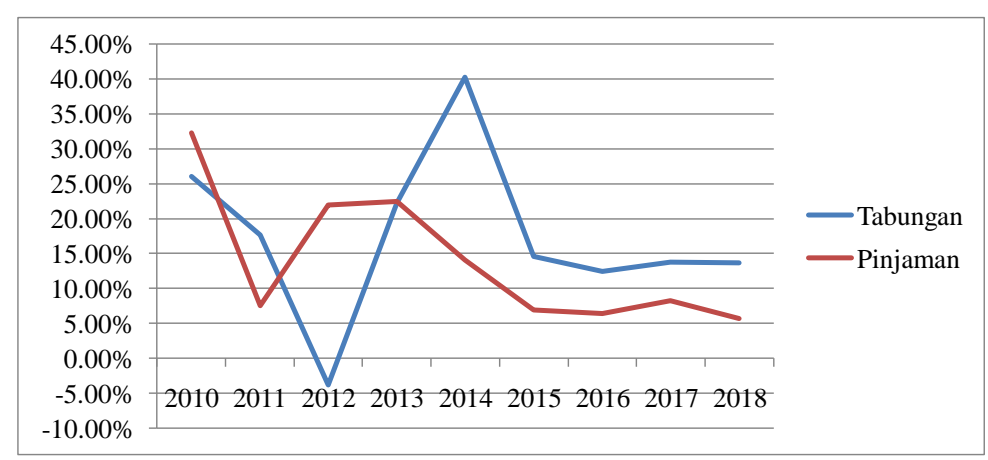

Saving

Loan

Figure 1. Percentage of Ngawi Regency Savings and Community Loan Development Period 2010 - 2018 Source: BPS Data Processing Results

Figure 1 above shows that the percentage of the development of savings and loans for the people of Ngawi Regency in 2010 - 2018 is very volatile. This means that there is a sharp up and down development. Such conditions have the potential to reduce monetary stability in Ngawi Regency. Determinants of community savings and loans in Ngawi Regency need to be studied in more depth in order to determine the right strategy and policy direction so that monetary conditions become more stable so that development runs smoothly and economic growth is headed in a better direction.

Efforts to increase savings and loans from the community by banks are also steps to ensure the survival of the bank itself. One of the efforts made is the policy of setting interest rates for savings and loans. This policy is expected to be able to attract the interest of the public to use the services of banks to either save or apply for a loan (credit). Employees as human resources (HR) in banks use this interest rate determination policy to attract customers. However, the data as presented in Figure 1 shows that the development of savings and loans of the people of Ngawi Regency in 2010 - 2018 experienced a sharp increase and decrease. This condition needs to know the cause so that people's interest in saving or applying for loans can be increased. The ability of HR to find customers is still low, the policy of determining interest rates that are less attractive or other determinants that affect savings and loans in the Ngawi Regency community.

Banking in Ngawi Regency needs to know the factors that influence people's willingness to save and apply for loans. This data can be used as an appropriate basis in determining the marketing strategy of savings and loan products marketed by banks in Ngawi Regency. Successful marketing of savings and loan products is expected to drive economic growth in Ngawi Regency. Job opportunities can be increased by the ease of obtaining business capital through bank loans, increasing community income so that people's purchasing power is stronger. It is also expected to be able to have an impact on inflation that provides opportunities for businesses and industries to grow due to the increase in selling prices of products, both goods and services offered. Banks can carry out their functions properly in maintaining monetary stability so that development can run smooth

Expert opinion and previous research findings supported by the initial data collection above, shows the importance of efforts to increase community savings and loans to support the achievement of development goals. This is interesting to do research with the title Determinants of Community Savings and Loans in Ngawi Regency in 2010 - 2018 A Micro Approach. 


\section{Review of Literature}

\subsection{Classical Theory}

According to Roswita, quoted by Deviana (2014), it is explained that in classical theory, interest rates determine the amount of savings and investment that will be made in the economy which causes the savings created in the full use of labor will always be the same as that done by employers. In the investment fund market there are savings groups, namely members of the community in a certain period have excess income from consumption needs and groups of investors in the same period need funds for investment to expand their business and will form a demand for loanable funds.

\subsection{Keynes's Theory}

Nopirin quoted by Deviana (2014) states that Keynes's Theory differs from the Classical Theory. In Keynes's theory it is stated that interest rates are a monetary phenomenon. This means that interest rates are determined by the supply and demand of money (in the money market). Money will affect economic activity (GNP), as long as this money affects interest rates. Changes in interest rates further affect the desire to invest thus affecting the GNP. Regarding the cost of holding cash, the higher the interest rate, the lower the desire to hold cash. From the explanation above, there is a negative relationship between interest rates and the demand for cash. Demand for this money will determine interest rates, interest rates are in balance if the amount of cash requested is equal to the offer.

\subsection{Interest Rates}

Sunariyah (2013) argues that interest rates are the price of loans. Interest rates can be expressed as a percentage value of the principal per unit time. Interest can be used as a measure of the price of resources used by debtors and must be paid to creditors. According to Kasmir (2015) interest is a service reward for the lender for the future benefits of the loan if invested. The loan amount is referred to as the principal debt. The percentage of the principal debt paid as a service fee over a period is called the interest rate.

\subsection{Savings}

Klasjok, et al (2018) in their research revealed that savings are a form of savings which can be withdrawn on conditions agreed upon, but cannot be withdrawn by check or other similar media. Furthermore Klasjok, et al (2018) explained that community savings are basically part of the income received by the community that is not used for consumption or in other words community savings are the difference between community income reduced by public consumption.

\subsection{Loans}

According to Muljono (2010) "credit is the ability to carry out a purchase or make a loan with a promise". Muljono (2010) explains that "credit is a transfer of money or bills that can be likened to it, based on an agreement or loan agreement between the Bank and another party that requires the borrower to repay the debt after a certain period of time with interest on the amount of compensation or profit sharing ".

\subsection{Gross Regional Domestic Product (GRDP)}

GRDP is the total value of goods and services produced in a particular region or region and within a certain period of time is usually one year. The high level of economic growth as indicated by the high value of GRDP shows that the region is experiencing progress in the 
economy (Dama, et al., 2016). According to BPS quoted by Weley (2017), Gross Regional Domestic Product (GRDP) is "the amount of added value that arises and all economic sectors in a particular region, or is the total value and final service goods produced by all economic units".

\section{Research Method}

This research is a type of quantitative research. The unit of analysis in this study is inter-time development data on the amount of savings and public loans, the determination of the interest rates on savings and loans on average per year, external funds, budget deficits, income, and inflation in Ngawi Regency during 2010-2018. The data analysis technique uses multiple linear regression in log-linear form with the following equation:

The first equation model

The first equation model

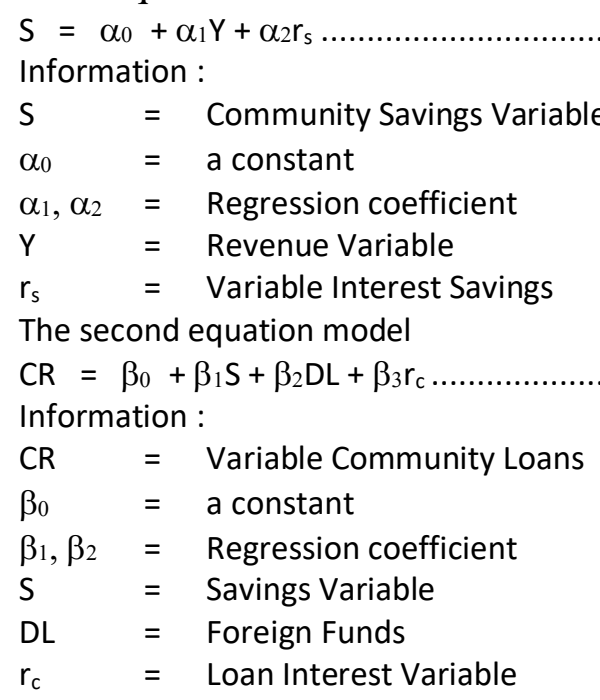

The influence of the independent variables on the dependent variable was tested with a confidence level of $95 \%$ or $\alpha=5 \%$. This study uses logarithms in the form of log-linear because of differences in the units of each variable studied.

\section{Discussion}

\subsection{First Equation Model}

The results of the data processing of the first equation using SPSS obtained the results as in the following table:

Table 2. Model First Equation

\begin{tabular}{|c|l|r|r|r|r|r|}
\hline No & Variable & Notation & $\begin{array}{c}\text { Regression } \\
\text { Coefficient }\end{array}$ & $\begin{array}{c}\text { Standard } \\
\text { Error }\end{array}$ & t count & \multicolumn{1}{c|}{ Prob } \\
\hline 1 & A constant & $\square_{\square}$ & $-24,814$ & 3,271 & -7.587 & 0,000 \\
\hline 2 & Income & $\mathrm{Y}$ & 2,835 & 0,250 & 0,959 & 11,356 \\
\hline 3 & Interest & $\mathrm{r}_{\mathrm{s}}$ & $-0,439$ & 0,505 & $-0,073$ & $-0,870$ \\
\hline $\mathrm{R}$ & & 0,980 & F Statistic & 71,581 \\
R-squared & 0,960 & Prob (F-Statistic) & 0,000 \\
Adjusted R-Squared & 0,946 & & & \\
\multicolumn{2}{|l|}{ S.E of regression } & 0,04385 & & & \\
\hline \multicolumn{2}{|l|}{ Dependent Variable: Community Savings (S) } \\
\hline
\end{tabular}

Source: SPSS Data Process Results for 2020 
The data in the table above shows that the Adjusted R-Squared value is 0.946. The variable of community savings can be explained by the variable income and interest savings of $94.6 \%$, while the remaining $5.4 \%$ is influenced by other factors which are not the subject of this study.

The calculated $F_{\text {value }}$ of 71.581 with a significance level of $0.000<0.05$. This means that the variable income and interest savings has a significant effect on community savings in Ngawi Regency.

Based on the data in the table above, the first equation model in this study is as follows:

$S=\alpha_{0}+\alpha_{1} Y+\alpha_{2} r_{s}$

$S=-24,814+2,835 Y-0,439 r_{s}$

An explanation of the above equation is as follows:

a. $\alpha_{0}=-24,814$, this shows that if the predictor variable or the independent variable is considered constant or assumed $=0$, then the magnitude of the contribution of the community saving variable is $-24,814$.

b. $\alpha_{1}=2.835$, this shows that the income variable (Y) has a positive effect on community savings. An increase in one unit of income variable will increase public savings (S) by 2,835 and assume another variable namely savings interest (rs) is constant.

c. $\alpha_{2}=-0.439$, this shows that the variable interest savings (rs) has a negative effect on community savings. An increase in one unit of interest on savings will reduce public savings (S) by -0.439 and assume another variable namely income (Y) is constant.

Partial $t$ test results can be seen that:

a. $\mathrm{T}_{\text {count }}$ value of income is 0.959 with a significance level of $11.356>0.05$. This means that income does not have a significant effect on community savings. Thus the hypothesis that says income has a significant effect on the savings of the people of Ngawi Regency is not proven and its truth is not accepted.

b. The t-value of the variable interest rate of savings is -0.073 with a significance level of $0.870>0.05$. This means that interest on savings does not significantly influence community savings. Thus the hypothesis that says savings interest has a significant effect on the savings of the people of Ngawi Regency is not proven and its truth is not accepted.

\subsection{The Second Equation Model}

The results of the data processing of the second equation using SPSS obtained the results as in Table 4.3, while the full calculation can be seen in Appendix 4.

Table 3. Second Equation Model

\begin{tabular}{|c|l|c|r|r|r|r|}
\hline No & \multicolumn{1}{|c|}{ Variable } & Notation & $\begin{array}{c}\text { Regression } \\
\text { Coefficient }\end{array}$ & $\begin{array}{c}\text { Standard } \\
\text { Error }\end{array}$ & t count & \multicolumn{1}{c|}{ Prob } \\
\hline 1 & A constant & $\beta_{0}$ & 0,208 & 0,879 & 0,236 & 0,823 \\
\hline 2 & Savings & $\mathrm{S}$ & 0,657 & 0,022 & 29,475 & 0,000 \\
\hline 3 & Foreign Funds & $\mathrm{DL}$ & 0,368 & 0,054 & 6,876 & 0,001 \\
\hline 4 & Loan interest & $\mathrm{r}_{\mathrm{c}}$ & $-0,199$ & 0,323 & $-0,615$ & 0,565 \\
\hline $\mathrm{R}$ & & 0,998 & F Statistic & 382,6040 \\
R-squared & 0,996 & Prob (F-Statistic) &, 000 \\
Adjusted R-Squared & 0,993 & & \\
S.E of regression & 0,01154 & & \\
\hline
\end{tabular}

Source: SPSS Data Process Results for 2020

The data in the table above shows that the Adjusted R-Squared value is 0.993. The variable of community loan can be explained by the variable of savings, external funds and 
loan interest of $99.3 \%$, while the remaining $0.7 \%$ is influenced by other factors which are not the subject of this study.

The calculated $\mathrm{F}$ value is 383,604 with a significance level of $0,000<0.05$. This means that the variable savings, external funds and interest loans have a significant effect on community loans in Ngawi Regency.

Based on the data in the table above, the first equation model in this study is as follows:

$C R=\beta_{0}+\beta_{1} S+\beta_{2} D L+\beta_{3} r_{c}$

$C R=0,208+0,657 S+0,368 D L-0,199 r_{c}$

An explanation of the above equation is as follows:

a. $\beta_{0}=0.208$, this shows that if the predictor variable or the independent variable is considered constant or assumed $=0$, then the magnitude of the contribution of the community loan variable is 0.208 .

b. $\beta_{1}=0.657$, this shows that the variable community savings (S) has a positive effect on community loans. An increase in one unit of the community savings variable will increase the community loan (CR) by 0.657 and assume other variables namely external funds (DL) and loan interest (rc) are constant.

c. $\beta_{2}=0.368$, this shows that the variable external funds (DL) has a positive effect on community loans. An increase in one unit of external funds will increase public lending $(\mathrm{CR})$ by 0.368 and assume other variables namely community savings (S) and loan interest (rc) are constant.

d. $\beta_{3}=-0.199$, this shows that the variable loan interest $(\mathrm{RC})$ has a negative effect on community loans. An increase in one unit loan interest will reduce community loans (CR) by -0.199 and assume other variables namely community savings (S) and external funds (DL) are constant.

Partial t test results can be seen that:

a. The tcount value of the community savings variable was 29.475 with a significance level of $0.00<0.05$. This means that community savings have a significant effect on community loans. Thus the hypothesis that says savings has a significant effect on the loans of the people of Ngawi Regency is proven and its truth is accepted.

b. Tcount value of external funds is 6.876 with a significance level of $0.001<0.05$. This means that external funds have a significant effect on community lending. Thus the hypothesis which reads outside funds has a significant effect on the loans of the people of Ngawi Regency is proven and its truth is accepted.

c. The $\mathrm{t}$-value of the variable loan interest is -0.615 with a significance level of $-0.565>$ 0.05 . This means that loan interest does not significantly influence community loans. Thus the hypothesis that the interest rates on loans have a significant effect on the loans of the people of Ngawi Regency is not proven and the truth is not accepted.

\subsection{The effect of income on community savings in Ngawi Regency.}

The effect of income on community savings in Ngawi Regency was analyzed based on the first equation model. Based on the results of hypothesis testing it is known that the correlation coefficient value of income to community savings is 2.835 , this shows that the income variable has a positive effect on community savings. An increase in one unit of income variable will increase public savings (S) by 2,835 and assume another variable namely savings interest (rs) is constant.

The results of the calculation of the hypothesis test also found the t-value of the income variable was 0.959 with a significance level of $11.356>0.05$. This means that income does not have a significant effect on community savings. Thus the hypothesis that says income has 
a significant effect on the savings of the people of Ngawi Regency is not proven and its truth is not accepted.

The results of this study do not support the findings of previous studies by Ritayani, et al. (2018) in Pekanbaru who found that the level of community income and interest rates was a factor that encouraged people to save. The findings of this study also do not support the results of Kay's study (2013) in Ambon City which found that the consumption variable influenced the savings of Ambon City society. The people of Ngawi Regency have a relatively low income, this is known from the UMK Ngawi Regency which occupies the third lowest position in East Java Province. Government banks in Ngawi Regency need to carry out better marketing strategies in increasing the acceptance of public savings. Efforts to increase the saving movement for the community need to be done continuously so that not all of the income earned is used for consumption needs.

\subsection{Effect of interest on savings on savings in the people of Ngawi Regency.}

The influence of the savings interest on the savings of the people of Ngawi Regency was analyzed based on the first equation model. Based on the results of hypothesis testing it is known that the correlation coefficient value of the savings interest variable to public savings is -0.439 , this shows that the variable interest savings has a negative effect on community savings. An increase in one unit of income variable will decrease public savings (S) by -0.439 and assume another variable, namely income $(\mathrm{Y})$, is constant.

The results of the calculation of the hypothesis test also found the value of t-count of savings interest variable was -0.073 with a significance level of $-0.870>0.05$. This means that interest on savings does not significantly influence community savings. Thus the hypothesis that says savings interest has a significant effect on the savings of the people of Ngawi Regency is not proven and its truth is not accepted.

The results of this study do not support the findings of previous studies by Ritayani, et al. (2018) in Pekanbaru who found that interest rates were a factor that encouraged people to save. The findings of this study also do not support the results of Moyo's study (2018) in South Africa which found that interest rate reforms had a positive impact on economic growth through savings and investment. The results of this study support the research findings of Wuhan, et.al. (2015) in Jiangsu Province of China that there is a negative relationship between interest rates and long-term investment. Savings interest rates are expected to increase people's interest in saving. However, in Ngawi Regency, interest rates do not have a real impact in attracting people to save. Interest rates are not the main factor that people consider saving.

\subsection{The effect of savings on the lending of the people of Ngawi Regency}

The effect of savings on community loans in Ngawi Regency was analyzed based on the second equation model. Based on the results of hypothesis testing, it is known that the correlation coefficient value of savings to community loans is 0.657 , this shows that the savings variable has a positive effect on community loans. An increase in one unit of the community savings variable will increase the community loan (CR) by 0.657 and assume other variables namely external funds (DL) and loan interest (rc) are constant.

The results of the calculation of the hypothesis test also found the t-value of the savings variable was 29.475 with a significance level of $0.00<0.05$. This means that community savings have a significant effect on community loans. Thus the hypothesis that says savings has a significant effect on the loans of the people of Ngawi Regency is proven and its truth is accepted. 
The results of this study support the findings of a previous study by Sari (2005) in South Sumatra which found that the collection of public funds had a (significant) effect on lending by commercial banks in South Sumatra. The findings of this study also support the research results of Puspawati, et al. (2016) in Denpasar who found that there was a positive and significant influence from Third Party Funds on the Number of Credit Distribution at PT BPR Bali Dananiaga Denpasar. Savings is a source of lending to the community. The results of this study found that savings had a significant effect on community loans in Ngawi Regency. Absorption of third party funds from the public is used as a revolving fund at the bank so that it can be used for lending to other people in need.

\subsection{Effect of loan interest on the lending of the people of Ngawi Regency.}

The influence of loan interest on community loan distribution in Ngawi Regency was analyzed based on the second equation model. Based on the results of hypothesis testing, it is known that the correlation coefficient of the loan interest variable to the community loan is 0,199 , this shows that the loan interest variable has a negative effect on the community loan. An increase in one unit loan interest will reduce community loans (CR) by -0.199 and assume other variables namely community savings (S) and external funds (DL) are constant.

The results of the calculation of hypothesis testing also found the value of tcount of savings variable was -0.615 with a significance level of $-0.565>0.05$. This means that loan interest does not significantly influence community loans. Thus the hypothesis that the interest rates on loans have a significant effect on the loans of the people of Ngawi Regency is not proven and the truth is not accepted.

The results of this study basically support the findings of previous studies by Rosyetti and Iyan (2010) in Riau which found that interest rates have a negative effect on lending. If there is an increase in the interest rate of credit, the distributed credit will decrease. The findings of this study also support the results of Sari and Abundanti (2016) research in Indonesian Banking which found that the SBI interest rate had no significant effect on lending to commercial banks. SBI interest rates experienced a fluctuation that was not too high and could not compensate for the increase in lending. Loan interest in this study also did not have a significant impact on lending to the public. People take loans when they need funds to meet various needs. Government banks in Ngawi Regency need to find information about the level of community needs that require funding from banks so that efforts to channel loans to the community can be optimized.

\subsection{The influence of external funds on the distribution of loans to the people of Ngawi Regency}

The influence of external funds on community loan disbursement in Ngawi Regency was analyzed based on the second equation model. Based on the results of hypothesis testing, it is known that the correlation coefficient value of external funds to public loans is 0.368 , this shows that the external funds variable has a positive effect on community loans. An increase in one unit of external funds will increase public lending (CR) by 0.368 and assume other variables namely community savings $(\mathrm{S})$ and loan interest (rc) are constant.

The results of the calculation of hypothesis testing also found the $t$-value of the external funds variable was 6.876 with a significance level of $0.001<0.05$. This means that external funds have a significant effect on community lending. Thus the hypothesis which reads outside funds has a significant effect on the loans of the people of Ngawi Regency is proven and its truth is accepted.

The External Fund (DL) in this study is the difference between total loans and total savings obtained from outside parties BRI and Bank Jatim to meet the credit demand of the 
people of Ngawi Regency. This difference must be fulfilled by banks so that credit requests can be fulfilled properly. To meet credit requests, sources of funds from outside the bank can be found, such as second parties and third parties. The results of this study basically support the findings of previous studies by Puspawati, et al. (2016) in Denpasar who found that there was a positive and significant influence from Third Party Funds on the Number of Credit Distribution at PT BPR Bali Dananiaga Denpasar. Outside funds can be used to balance the availability of funds with demand for credit. Availability of funds sourced from outside the bank is needed when the demand for credit or loans by the public is higher.

\subsection{The right theory is applied in order to increase the receipt of savings and lending to} the people of Ngawi Regency

Nopirin's opinion was quoted by Ritayani (2018), stating that in classical theory high interest rates would lead to high volumes of public savings. In addition, high interest rates will also result in surging corporate capital costs, so that competition in investment will occur, meaning that investors tend to invest in the money market or savings rather than in the capital market. Conversely, low interest rates, both lending rates and deposit rates, will have the effect of reducing people's desire to save while companies can take credit to increase capital or investment with low interest. The Classical View which states that the higher the interest rate, the more savings will be made by the public.

Keynes in his theory of the propensity to consume that explicitly links savings and income to society that income is said to be one of the factors that influence saving. The classic that determines investment saving is the interest rate, then Keynes argues that income determines saving.

The results of hypothesis testing found that savings and loan interest rates did not significantly influence the savings and loans of the people of Ngawi Regency. Both of these findings indicate that the right theory applied to increase the receipt of savings and lending Ngawi Regency is Keynes's theory. Keynes said that the interest rate is a payment for users of scarce resources (money). The interest rate is the price issued by the debtor to encourage a creditor to move these scarce resources. However, the money spent by the debtor accepts the possibility of loss in the form of the risk of not receiving a certain interest rate.

The explanation above shows that interest rates according to Keynes's view are not the main factors that encourage people to save or borrow money from a bank. This is consistent with the empirical findings of the study, so that state banks in Ngawi Regency need to look for other marketing strategies in addition to determining interest rates to increase savings receipts and lending to the public.

\section{Conclusion}

1. Income has no real impact on the savings of the people of Ngawi Regency. The people of Ngawi Regency have a relatively low income, this is known from the UMK Ngawi Regency which ranks third lowest in East Java Province so that people's interest in saving is also low.

2. The determination of savings interest does not support the receipt of savings from the people of Ngawi Regency in BRI and Bank Jatim. Interest rates are not the main factor that is considered by the public to save money.

3. Savings can increase community loan in Ngawi Regency. Absorption of third party funds from the public is used as a revolving fund at the bank so that it can be used for lending to other people in need. 
4. The policy for determining loan interest rates carried out by BRI and Bank Jatim is less able to have a real impact on the distribution of loans to the people of Ngawi Regency. Loan distribution is less than optimal by relying on loan interest policy.

5. External funds are able to encourage the fulfillment of Ngawi Regency community loan disbursement. External funds can be used to balance the availability of funds with requests for community loans.

6. Savings and less interest can be used to increase the savings and loans of the people of Ngawi Regency. This shows that the right theory applied to increase the receipt of savings and lending Ngawi Regency is Keynes's theory.

\section{References}

Bhattarai, Yuga Raj. (2015). "Determinants of Lending Interest Rates of Nepalese Commercial Banks", Economic Journal of Development Issues, Vol. 19 \& 20 No. 1-2, pp. 39-59

Dama, H.Y., Lapian, A.L.C., dan Sumual, J.I. (2016). "Pengaruh Produk Domestik Regional Bruto (PDRB) Terhadap Tingkat Kemiskinan di Kota Manado (Tahun 2005-2014)", Jurnal Berkala Ilmiah Efisiensi, Volume 16 No. 03, hal. 549-561

Deviana, Nyimas. (2014) "Analisis Pengaruh Suku Bunga Sbi, Suku Bunga Kredit Dan Nilai Tukar Terhadap Inflasi Di Indonesia Periode Tahun 2006 - 2012”, Jurnal Ekonomi Pembangunan, Volume 12, No. 2, Hal. 81 - 91

Fithriyah, Zulfita., dan Nazaruddin Malik. (2010). "Pengaruh Kredit Perbankan Terhadap Pertumbuhan Industri Manufaktur Dalam Menunjang Pertumbuhan Ekonomi Indonesia", Jurnal Ekonomi Pembangunan, Vol 8 No. 1, hal. 209-214

Kairupan, S.P. (2013) "Produk Domestik Regional Bruto (PDRB), Inflasi Dan Belanja Daerah Pengaruhnya Terhadap Kesempatan Kerja Di Sulawesi Utara Tahun 20002012”, Jurnal EMBA, Vol.1 No.4, hal. 2206-2216

Kasmir. (2016) Bank dan Lembaga Keuangan Lainnya, Edisi Revisi, Jakarta : PT. Rajagrafindo Persada

Kay, Vera Paulin. (2013) "Tabungan Dan Variabel Ekonomi Makro Yang Mempengaruhinya Di Kota Ambon”, Cita Ekonomika, Vol.VII, No.1, ISSN: 1978-3612, hal. 95-100

Laksono, R. Roosaleh. (2017) "Analisis Faktor-Faktor Yang Mempengaruhi Suku Bunga Pinjaman Bank Umum Di Indonesia Melalui Pendekatan Kointegrasi Dan Error Correction Model (ECM)", Proceedings Profesionalisme Akuntan Menuju Sustainable Business Practice, ISSN- 2252-3936, hal. 362-375

Lengkong, Nadya Lani, Vekie A. Rumate, dan Daisy S.M. Engka. (2018) "Pengaruh PDRB, Inflasi Dan Suku Bunga Terhadap Tingkat Tabungan Masyarakat Pada Bank Sulutgo”, Jurnal Pembangunan Ekonomi Dan Keuangan Daerah, Vol. 19 No. 5, hal. 1 - 14

Moyo, Clement. (2018) "Interest rate reforms and economic growth: the savings and investment channel", Munich Personal RePEc Archive, pp. 1-22

Muljono, Teguh Pudjo. (2010) Manajemen Perkreditan Bagi Bank Komersiil, Edisi 4, Yogyakarta : BPFE

Mushtaqn, Saba and Danish Ahmed Siddiqui. (2017) "Effect of interest rate on bank deposits : Evidences from Islamic and non-Islamic economies", Future Bussiness Journal, Vol. 3, pp. 1-8

Nur, Asad Ridjal. (2015) "Pengaruh Suku Bunga Terhadap Deposito Studi Kasus Pada PT. Bank Rakyat Indonesia (Persero) Tbk Cabang Makassar", MINDS Jurnal Manajemen Ide dan Inspirasi, Vol. 2 No. 2, hal. 68-84 
Persaulian, Baginda, Hasdi Aimon, dan Ali Anis. (2013) "Analisis Konsumsi Masyarakat Di Indonesia", Jurnal Kajian Ekonomi, Vol. I, No. 02, hal. 1-23

Puspawati, L., Cipta, W., dan Yulianthini, N.Y. (2016) "Pengaruh Dana Pihak Ketiga Dan Jumlah Penyaluran Kredit Terhadap Laba", e-Journal Bisma Universitas Pendidikan Ganesha Jurusan Manajemen, Volume 4, hal. 1-8.

Raza, Hasan, Samreen Hena \& Atiya Saeed. (2017) "The Effects Of Interest Rate, On Savings And Deposits In Pakistan", International Journal of Business and General Management (IJBGM), Vol. 6, Issue 6, pp. 67-74

Ritayani Iyan, Rosyetti dan Susie Lenggogeni. (2018) "Faktor-Faktor Yang Mempengaruhi Tabungan Masyarakat Pada Bank Umum Di Pekanbaru”, Jurnal Ekonomi, Vol. 26 No. 4, hal. 1-14

Rosyetti dan Eriyati. (2011) "Pengaruh Defisit Anggaran Terhadap Inflasi Di Indonesia Tahun 1981-2010", Jurnal Ekonomi Universitas Riau, hal. 1-9

Rosyetti dan Iyan, R.Y. (2010) "Peran Dana Pihak Ketiga dan Tingkat Suku Bunga Kredit Terhadap Penyaluran Kredit Investasi Pada Bank Umum di Provinsi Riau”, Jurnal Ekonomi, Vol. 10 No. 2, hal. 92-107

Sari, A.D.M. (2005) "Pengaruh Dana Masyarakat Terhadap Penyaluran Kredit Pada Bank Umum Di Sumatera Selatan Periode 1994-2004”, Jurnal Ekonomi Pembangunan, Vol. 3 No. 2, hal. 127 - 143

Sari, N.M.J., dan Abundanti, N. (2016) "Pengaruh Dpk, Roa, Inflasi Dan Suku Bunga SBI Terhadap Penyaluran Kredit Pada Bank Umum”, E-Jurnal Manajemen Unud, Vol. 5, No. 11, ISSN: 2302-8912, hal. 7156-7184

Sassi, S. and Gasmi, A. (2014) "The effect of enterprise and household credit on economic growth: New evidence from European union countries", Journal of Macroeconomics, 39, pp. 226-231

Siwi, Janet Aprilia, Vekie A. Rumate, dan Audie O. Niode. (2019) "Analisis Pengaruh Tingkat Suku Bunga Terhadap Permintaan Kredit Pada Bank Umum Di Indonesia Tahun 2011-2017”, Jurnal Berkala Ilmiah Efisiensi, Volume 19 No. 01, hal. 1-9

Suhel, Mardalena. (2015) "Analisis Kausalitas Antara Tabungan Masyarakat Dengan Pertumbuhan Ekonomi Di Kota Palembang (Tahun 1995-2013)", Jurnal Ekonomi Pembangunan, Volume 32, No. 2, hal. 86 - 95

Sunariyah. (2013) Pengantar Pengetahuan Pasar Modal (Edisi 6), Yogyakarta : UPP. STIM YKPN

Susanti, S. (2013) "Pengaruh Produk Domestik Regional Bruto, Pengangguran dan Indeks Pembangunan Manusia terhadap Kemiskinan di Jawa Barat dengan Menggunakan Analisis Data Panel", Jurnal Matematika Integratif, ISSN 1412-6184, Vol. 9 No. 1, hal. $1-18$

Ulfha, S R. (2019). Role of Knowledge Sharing and Organizational Commitment to Development Micro Small and Medium Enterprises (MSMEs). Budapest International Research and Critics Institute-Journal (BIRCI-Journal). pp. 307-312.

Utami, Dyah. (2012) "Determinan Suku Bunga Pasar Uang Antar Bank (PUAB) di Indonesia", JEJAK, Volume 5, Nomor 1, Maret 2012, hal. 26-35

Wuhan, Li Suyuan, Adnan Khurshid. (2015) "The effect of interest rate on investment; Empirical evidence of Jiangsu Province, China", Journal of International Studies, Vol. 8, No 1, pp. 81-90 